\title{
Autism Spectrum Disorders in an Upper-Middle Income Country
}

\author{
${ }^{1}$ Children's Psychiatric Hospital, Mexico \\ ${ }^{2}$ National Autonomous University of Mexico, Mexico \\ ${ }^{3}$ Emergency Department, Mexico \\ ${ }^{4}$ Institute of Security and Social Services of State Workers, Mexico \\ ${ }^{5}$ National Institute of Psychiatry, Mexico \\ ${ }^{6}$ Spanish Hospital, Mexico
}

Liliana Tapia Guillen ${ }^{1,2}$, Marco A Solis Bravo ${ }^{1,2}$, Lilia Albores Gallo ${ }^{1,2 *}$, Yassel Flores Rodriguez ${ }^{3}$, Ofelia Roldan Ceballos $^{4}$, Romina Erika Aguerre Estevez ${ }^{5}$ and Jimena Martin Salas ${ }^{6}$

Submission: Febuary 04, 2019; Published: March 01, 2019

*Corresponding author: Lilia Albores Gallo, Department of Genetic, Clinical and Community Epidemiology, Children's Psychiatric Hospital, National Autonomous University of Mexico, Tlalpan 14080, Mexico City, Mexico

\begin{abstract}
The detection of Autism Spectrum Disorders (ASD) in Mexico has been a challenge. Parents, health and educational professionals lack knowledge of key symptoms causing delay in diagnosis, intervention and early treatment. Almost $76 \%$ of parents ( $N=92$ ) expressed their first concern at $23.8(\mathrm{SD}=13.1)$ months, with a mean diagnosis delay of $41.8(\mathrm{SD}=35.2)$ months. The referral for a specialized assessment was suggested by medical doctor (35.8\%), followed by teachers (27.4\%), and psychologists (17.9\%). Three professionals were contacted to obtain a formal diagnosis. Parents lose average 6.3 days of work per month to attend for their children's treatment appointments. Our findings can help develop better health and educational services to achieve timely diagnosis, and early intervention treatment.

Keywords: Diagnostic delay; Autism spectrum disorders; México; Economic burden
\end{abstract}

\section{Introduction}

In México, the prevalence of autism has been poorly studied, until [1], reported a prevalence rate of $0.89 \%(95 \%$ CI, $0.62-1.1 \%$ ) for León, Guanajuato; in the same study, $70 \%$ of parents of children with ASD had concerns about their atypical development between 18 and 36 months of age, almost half of them had a first contact with health services at 24 to 36 months, but a formal diagnosis was reached between 36-60 months of age, or after, in $80 \%$ of the families. These data are consistent with a retrospective study $(\mathrm{N}=323)$ from a Mexican neurological center showing that the mean age of detection was 4 years old and the primary cause of parental concern was language delay or regression in $60 \%$ of the children [2].

Many studies show that most parents detect the signs and symptoms of ASD before 24 months of age [3-5] but the formal diagnosis is made 2 to 4 years later [6]. The delay is longer in low and middle-income countries compared to high-income countries (5.5-6 years vs. 4) [7]. Among Hispanics there is an important lack of knowledge concerning developmental delays affecting the awareness and demand for assessment [8-10].

The diagnostic process is stressful, complex and difficult, this makes parents postpone [9,11-13], and when complaints are expressed to pediatricians many prefer to wait until the child is older to refer for assessment and lack important information about the early symptoms of autism [14] in contrast pediatricians in other countries are the first professional to refer for treatment $[12,15]$.

In addition, in Mexico and Latinamerica very few diagnostic and screening instruments for autism have been formally validated [16-23]. Most centers use non-validated Spanish versions of these tools which were designed in Anglo-Saxon countries and have cultural biases that diminish their effectiveness when applied in countries with different languages than English such as the M-Chat or have different cutoff points like the ABC $[17,24]$, or different total mean values compared to the original studies [19]. 
Moreover, timely diagnosis gives the opportunity to assess other siblings or family members with attenuated forms of the disorder and to receive genetic counselling. The age of detection, and other variables may differ depending on the recruitment setting, this is why we are interested in knowing the characteristics of children seeking attention in a psychiatric outpatient service. The aim of this study is to improve this knowledge which will be useful for the planning of services and public policy for this population.

\section{Material and Methods}

\section{Type of design}

A descriptive, prospective, cross-sectional observational study was conducted.

\section{Sample}

Participants were patients with a confirmed diagnosis of Autism Spectrum Disorder through a semi-structured clinical interview based on DSM-IV criteria and diagnostic instruments such as ADI-R, and/or CARS administered by an experienced child psychiatrist.

\section{Procedure}

Parents of children and adolescents $(\mathrm{N}=135)$ with a confirmed ASD diagnosis were invited to participate in the survey, with a response rate of $78.7 \%$.

\section{Measuring instruments}

A survey was completed by the parents (Table 1).

Table 1: Sociodemographics and other variables of the study

\begin{tabular}{|c|c|c|c|c|}
\hline & $\begin{array}{c}\text { Autism } \\
(\%) \\
50(52.6)\end{array}$ & $\begin{array}{c}\text { Asperger } \\
(\%) \\
26(27.4 \%)\end{array}$ & $\begin{array}{c}\text { PDDNOS } \\
(\%) \\
19(20 \%)\end{array}$ & $\begin{array}{c}\text { Total ASD } \\
\text { (\%) } \\
95(100)\end{array}$ \\
\hline Male N (\%) & $42(84.0)$ & $21(80.8)$ & $12(63.2)$ & $75(78.9)$ \\
\hline \multicolumn{5}{|l|}{ Age (years/months) M(SD) } \\
\hline Child ${ }^{* * *}$ & $78.8(32.4)$ & $108.7(41.7)$ & $100.4(54.0)$ & $91.3(41.9)$ \\
\hline Father & $37.7(7.1)$ & $37.8(6.6)$ & $41.2(8.6)$ & $38.5(7.4)$ \\
\hline Mother* & $33.8(5.8)$ & $34.3(6.5)$ & $39.8(10.8)$ & $35.1(7.4)$ \\
\hline SES (SD) & $5.6(3.0)$ & $5.0(0)$ & $6.5(2.0)$ & $5.8(2.7)$ \\
\hline Monoparental family N(\%) & $8(16.3)$ & $10(40.0)$ & $6(31.6)$ & $24(28.8)$ \\
\hline ASD cause of separation/divorce $\mathrm{N}(\%)$ & $4(57.1)$ & $2(20)$ & $2(33)$ & $8(34.8)$ \\
\hline Initial concern yes/no N (\%)* & $48(96)$ & $26(100)$ & $18(94.7)$ & $92(96.8)$ \\
\hline Age in months of first concern M(SD) & $21.0(11.6)$ & $26.2(15.2)$ & $27.8(11.8)$ & $23.8(13.1)$ \\
\hline \# Professionals before diagnosis M(SD) $\dagger$ & $3.2(3.5)$ & $3.3(3.0)$ & $3.5(2.6)$ & $3.3(3.2)$ \\
\hline Diagnosis delay (months) M(SD) & $35.4(30.1)$ & $42.4(28.3)$ & $55.1(48.6)$ & $41.8(35.2)$ \\
\hline Other Previous diagnosis (\%) & $26(52)$ & $15(57.6)$ & 7 (36.8) & $48(50.5)$ \\
\hline Comorbid non psychiatric illness N (\%) & $5(10)$ & $5(19.2)$ & $1(5.3)$ & $11(11.6)$ \\
\hline Medication prescribed for this illness N (\%) & $5(10)$ & $2(8)$ & $1(5.3)$ & $8(8.5)$ \\
\hline Medications prescribed for ASD M(SD) & $1.5(0.9)$ & $1.6(1.0)$ & $1.6(0.8)$ & $1.5(0.94)$ \\
\hline Cost of medications in Dollars $\dagger \dagger$ & $75.9(57.8)$ & $53.9(44.6)$ & $109.0(52.6)$ & $77.1(56.05)$ \\
\hline Minimum wage (4.6 Dlls/day) \# of days & $16.51(12.5)$ & $11.73(9.71)$ & $23.7(11.43)$ & $16.7(4.18)$ \\
\hline Other therapies yes/no N (\%) & $29(58)$ & $18(69.2)$ & $8(42.1)$ & $55(57.9)$ \\
\hline Cost of therapies in Dollars M(SD)†† & $55.7(54.7)$ & $38.9(34.0)$ & $33.8(24.2)$ & $48.1(46.9)$ \\
\hline Minimum wage (4.6 Dlls/day) \# days M (SD) & $12.1(11.91)$ & $8.4(7.4)$ & $7.36(5.2)$ & $10.4(10.2)$ \\
\hline Days of work lost/ month M (SD) & 7.0 (11.4) & $3.4(3.8)$ & 8.5 (12.4) & $6.3(10.2)$ \\
\hline
\end{tabular}

Note: SES: Number of lights bulbs inside the household; $\uparrow 11.76 \%$ reported not having consulted any professional before receiving a formal diagnosis. ††2007 average exchange rate; ${ }^{*} p \leq .05,{ }^{* *} p \leq .01, p \leq{ }^{* * *} .001$ 


\section{Statistical analysis}

Group differences in categorical variables such as sex, subtype of ASD, type of family (monoparental vs. other) ASD as cause of separation (yes/no), initial concern yes/no, other previous $\mathrm{dx}$ (yes/no), comorbidity with non psychiatric disorders (yes/ no), medication prescription (yes/no), other therapies (yes/ no) were analyzed through chi square. Quantitative variables such as parents and child age, age of first concerns, number of professionals consulted, diagnosis delay in months, number of medications prescribed, cost of medication, minimum wage per day, cost of therapies, days of work lost per month were analyzed through analysis of variance (ANOVA).

Result

\section{Sociodemographics}

Twelve participants were removed from the study due to incomplete survey data. The final sample consisted of 95 children with autism spectrum disorder, of whom 78.9\% (N=75) were male, with an average age of 91.3 months (SD 41.9).

\section{Parental age}

The mean age of the parents in the total sample and all subgroups was higher for the father compared to the mother: 38.5(7.4) vs. 35.1(7.4), PDDNOS 41.2(8.6) vs. 39.8(10.8), Asperger $37.8(6.6)$ vs $34.3(6.5)$ and the Autism 37.7(7.1) vs. 33.8(5.8) years (Table 1$)$.

\section{Developmental concerns}

Most of the parents (96.8\%) had preoccupations about their child development, percentage was higher in the Asperger group (100\%), followed by Autism (96\%) and PDDNOS (94.7\%). The mean age of parental concern for the total sample was 23.8 months, the earliest concern was in the Autism group at 21 months, followed by the Asperger group at 26.2 months and the PDDNOS group at 27.8 months.

\section{Referral for assessment}

School and health professionals who referred the children for specialized assessment were physicians in $38.2 \%$ of cases, followed by teachers (27.4\%), and psychologists (19.1\%). Close relatives suggested that the child should be evaluated by an expert in $7.9 \%$ of cases, and $5.6 \%$ of children were assessed at the request of their parents.

\section{Diagnosis}

A formal diagnosis for the total sample was made until 41.8 months of age, for Autism at 35.4, Asperger at 42.4 and PDDNOS at 55.1. Almost half of the children receive a previous diagnosis other than ASD being ADHD the most common diagnosis.

\section{Cost of treatment}

The number of medications prescribed was between 1.5 and 1.6. The average cost of medication was between 53.9 and 109 dollars (dlls); in 2007 the daily minimum wage (dmw) in
Mexico was 4.6 dlls, so in order to buy medication for one month, parents would have to earn between 11.73 and $26.7 \mathrm{dmw}$. In addition, parents reported that $57.9 \%$ of the children with ASD receive additional behavioral and language therapy, with an average cost of 48.1 dlls per month, meaning that they would have to earn a corresponding $10.4 \mathrm{dmw}$. The average cost of the combined treatment (medications, language, behavioral and other therapies) would be $27.1 \mathrm{dmw}$.

\section{Work productivity losses}

Most of the mothers answered the survey, 46\% them were housewives, the rest $(54 \% \mathrm{~N}=51)$ reported losing between 3.5 and 9.5 days of work per month to attend for the children's medical appointments.

\section{Discussion}

In this study, we investigated the diagnosis delay in children with ASD and associated factors in a clinical sample.

\section{Sociodemographics}

As other studies we found a higher ratio of males vs. females 4:1 [25-29]. However, a recent study reported that the most reliable ratio between sexes is 3:1 given the higher risk of females to be underdiagnosed [30].

Almost 29\% of the families were monoparental, from these $34.8 \%$ considered having a child with ASD was a major reason for separating, but there is no evidence that children with ASD are at increased risk for living in a household not comprised of 2 parents [31]. However, the percentage reported in this study is higher compared to the general population of Mexico; $16.8 \%$ in 2010 and $21 \%$ in 2015 [32].

\section{Parental age}

The average age of the parents at time of conception for the total sample was 30.9 vs. 27.5 for fathers and mothers respectively. This figure is higher than the age of the first pregnancy for Mexican women which is 21.1 years [33], and 24 for men for their first child [34].

The role of advanced maternal age in ASD has not been well established; evidence show that women above 40 and below 19 have a higher risk for having a child with ASD [35-38]. The association is stronger for the father's age $[39,50]$; but the causal effects of the parental age for elevating the risk of autism are still unknown [41].

\section{Developmental concerns}

Consistent with other studies [51-53], nearly 97\% of the respondents had preoccupations concerning their child's development The average age of first concern was 23.8 months for the total sample, which was earliest in the Autism group (21.0) compared to Asperger and PDDNOS (26.2 and 27.8) these results are consistent with other studies [12,54-56] but inconsistent with other [3]. 


\section{Global Journal of Intellectual \& Developmental Disabilities}

\section{Referral for assessment}

On average, parents contacted 3.3 health professionals before receiving a reliable diagnosis; which was similar for all groups, consistent with other studies [26,56,57]. We must point out that access to mental health services in Mexico City is much better compared to other states of the country. In 2012, half of the board certified child psychiatrists $(\mathrm{N}=223)$ practiced in Mexico City [58,59].

Professionals who were more likely to refer patients for a clinical assessment were medical doctors (35.8\%), teachers $(27.4 \%)$ and psychologists (17.9\%). Our results suggests that teachers play a significant role in the identification and referral of children with autism as mentioned by other researchers $[60,61]$.

Compared to a Spanish study where the majority of the families took the initiative for seeking attention [62], only 5.6\% of Mexican parents had the same initiative. The important role of relatives has been noted finding that frequent interaction with grandparents lowers the age of recognition by 5 months [63].

\section{Diagnostic delay}

The diagnostic delay in months for the total sample was 41.8 months (range 1-182), for Autism 35.4, for Asperger 42.4 and for PDDNOS 55.1; although it is important to note that our results do not reflect the general situation in Mexico. Our results are similar to other studies in which parents usually recognize symptoms of autism before 24 months of age and the mean age at diagnosis ranges from 38 to 120 months [2,64-72].

Contrasting with Asperger and PDDNOS, several studies report autism is consistently diagnosed earlier, probably due to its more severe and earlier symptoms $[60,73,74]$. Diagnostic delay persists even in high income countries which is 3.5 years between the first healthcare professional contact and the formal diagnosis of ASD in the United Kingdom [60], this is consistent with other studies reporting a time lag of nearly three years in receiving a diagnosis $[60,65,68,75,76]$.

In Mexico reasons for this delay might be different, for example, a common practice is to withhold the diagnosis of autism from patients and parents in the educational and medical sector, this unethical practice reflects the stigma around mental health disorders [77,78]. Lack of knowledge is also a common problem in Mexico, as in other countries [14,79,80] sustitute comma for a dot. Also, many family physicians lack training in diagnosis and do not know where to refer patients with autism; moreover, they are unfamiliar with screening tools and reported having little time to perform this type of assessment [81].

Studies from high income countries have a reported that only $6 \%$ of mental health providers feel comfortable providing a diagnosis of ASD and very few have training to conduct assessment for this disorder [82]. Since Mexico has similar problems, in 2018, the Mexican government reformed the law to include a formal and early diagnosis as a fundamental right for people with ASD and their families [83].

\section{Cost of treatment}

Most parents reported their children received a mean of 1.5 medications with an average cost of 77.1 dlls per month representing $16.4 \mathrm{dmw}$. We also demonstrated a negative impact on the availability of the caregivers to work as reported in other studies [84]. In general, parents spend more time and money on their children and consequently earn less.

The mean number of medications prescribed was similar for all groups, but, contrary to our expectations the PDDNOS group spent the most on medications prescribed ( $\$ 109.0$ dlls) representing $23.7 \mathrm{dmw}$. Usually the PDDNOS is a diagnosis assigned to individuals with milder forms of autism. A possible explanation is that the PDDNOS group had higher SES so probably their physician chose to prescribe more medications and with a higher cost.

In Mexico, the Seguro Popular [85], covers psychiatric care for ASD comprising a wide range of medications, melatonin to treat sleep disorders commonly associated with autism is not included despite its usefulness and minimal side effects [86], it also leaves out genetic testing, counselling, diagnostic and psychological testing, language and occupational therapy, and intensive behavioral treatment. In contrast, in the United States, health coverage of early intensive behavioral intervention (EIBI) for children with autism spectrum disorder (ASD) is increasingly becoming the norm $[87,88]$.

\section{Limitations}

The information was collected in a clinical child psychiatric setting which does not reflect the condition of the problem in the general population. As mentioned earlier, it would be important to perform similar studies in the community, in rural settings and other Mexican states. The study sample had access to lower prices for medications and therapies, families not attending the same institution would probably have more expenses. Another important limitation was the lack of measurements of intellectual quotient in the majority of children, so we could not analyze the effect of this important variable in the diagnostic delay and costs in general. Future studies should focus on the diverse complex trajectories' parents follow to get a formal diagnosis and treatment.

\section{Acknowledgements}

The authors would like to thank Dr. Patricia Zavaleta Ramirez for reviewing the draft manuscript and giving important suggestions.

\section{References}

1. Fombonne E, Marcin C, Manero AC, Bruno R, Diaz C, et al. (2016) Prevalence of Autism Spectrum Disorders in Guanajuato, Mexico: The Leon survey. J Autism Dev Disord 46(5): 1669-1685. 


\section{Global Journal of Intellectual \& Developmental Disabilities}

2. Bravo Oro A, Vázquez Briseño J, Cuello García CA, Calderón Sepúlveda RF, Hernández Villalobos AM, et al. (2012) Manifestaciones iniciales de los trastornos del espectro autista. Experiencia en 393 casos atendidos en un centro neurológico infantil. Neurología 27(7): 414-420.

3. Chawarska K, Paul R, Klin A, Hannigen S, Dichtel LE, et al. (2007) Parental Recognition of Developmental Problems in Toddlers with Autism Spectrum Disorders. J Autism Dev Disord 37(1): 62-72.

4. Herlihy L, Knoch K, Vibert B, Fein D (2015) Parent's first concerns about toddlers with autism spectrum disorder: Effect of sibling status. Autism 19(1): 20-28.

5. Ozonoff S, Young GS, Steinfeld MB, Hill MM, Cook I, et al. (2009) How early do parent concerns predict later autism diagnosis. J Dev Behav Pediatr 30(5): 367.

6. Kishore MT, Basu A (2011) Early concerns of mothers of children later diagnosed with autism: Implications for early identification. Research in Autism Spectrum Disorders 5(1): 157-163.

7. Samms Vaughan ME (2014) The status of early identification and early intervention in autism spectrum disorders in lower- and middleincome countries. Int J Speech Lang Pathol 16(1): 30-35.

8. Ijalba E (2016) Hispanic Immigrant Mothers of Young Children With Autism Spectrum Disorders: How Do They Understand and Cope With Autism? American Journal of Speech-Language Pathology 25(2): 200213

9. Zuckerman, Katharine E, Chavez AE, Murillo CR, Lindly OJ, et al. (2018) Disparities in Familiarity with Developmental Disabilities among LowIncome Parents. Acad Pediatr 18(8): 944-951.

10. Zuckerman, Katharine Elizabeth, Lindly OJ, Sinche BK (2015) Parental Concerns, Provider Response, and Timeliness of Autism Spectrum Disorder Diagnosis. J Pediatr 166(6): 1431-1439.e1.

11. Albores Gallo L, Hernandez Guzman L, Antonio Diaz Pichardo J, Cortes Hernandez B (2008) Difficulties in assessing and measuring autism. A discussion Salud Mental 31(1): 37-44.

12. Crane L, Chester JW, Goddard L, Henry LA, Hill E (2016a) Experiences of autism diagnosis: A survey of over 1000 parents in the United Kingdom. Autism 20(2): 153-162.

13. Dabrowska A, Pisula E (2010) Parenting stress and coping styles in mothers and fathers of pre-school children with autism and Down syndrome. J Intellect Disabil Res 54(3): 266-280.

14. Zuñiga E, Sanchez Lizardi P, Pego A, Romero L (2017) Mexican Pediatricians' Role in the Early Identification and Intervention of Autism Spectrum Disorder. En Annual Meeting of The International Society for Autism Research, pp. 713-714.

15. Grupo de Estudios de los Trastornos del Espectro Autista IIER/ISCIII. (2004a). Informe sobre Demora Diagnóstica en los TEA (Investigación). España: Instituto de Salud Carlos III, p. 1-43.

16. Albores Gallo L, Lopez Figueroa A, Nafate Lopez O, Hilton CL, Flores Rodriguez Y, et al. (2016) Psychometric properties of VEAN-Hi (Valoracion del Espectro Autista para Hispanos), Autism Spectrum Assessment for Hispanic Children (ASA-HiCh) A free open access instrument. Neuropsychiatry 6(3): 88-95.

17. Albores Gallo L, Roldán Ceballos O, Villarreal Valdes G, Betanzos Cruz BX, Santos Sánchez C, et al. (2012) M-CHAT Mexican Version Validity and Reliability and Some Cultural Considerations. ISRN Neurology 2012: 408694.

18. Flores Rodriguez Y, Albores Gallo L (2016) 1.33 VALIDITY OF MEXICAN CARS VERSION. Journal of the American Academy of Child \& Adolescent Psychiatry 55(10): S110.

19. Fombonne E, Marcin C, Bruno R, Tinoco CM, Marquez CD (2012) Screening for Autism in Mexico. Autism Res 5(3): 180-189.
20. Living Varela K, Albores Gallo L (2012) Confiabilidad y Validez del Inventario de comportamiento autista $(\mathrm{ABC})$ en niños con trastornos del espectro autista. UNAM, México, D.F.

21. Lopez Martínez W, Albores Gallo L (2011) Validez de la cédula ADOS-G para diagnóstico del autismo en población Mexicana. Universidad Nacional Autónoma de México UNAM, México, D.F.

22. Zavaleta Ramírez P, Náfate López O, Villarreal Valdés G, Ulloa Flores RE (2014) Confiabilidad interevaluador del K-SADS-PL-2009/trastornos del espectro autista (TEA). Salud Mental 37(6): 461-466.

23. Young RL (2007) Autism Detection in Early Childhood: ADEC Manual. (Australian Council of Educational Research).

24. Albores Gallo L (2013) Assessing Autism in Mexico Through the Autism Behavior Checklist (ABC). International Meeting for Autism Research, Spain: International Society for Autism Research, pp.70-71.

25. Elsabbagh M, Divan G, Koh YJ, Kim YS, Kauchali S, et al. (2012) Global Prevalence of Autism and Other Pervasive Developmental Disorders: Global epidemiology of autism. Autism Res 5(3): 160-179.

26. Goin Kochel RP, Mackintosh VH, Myers BJ (2006) How many doctors does it take to make an autism spectrum diagnosis? Autism 10(5): 439451.

27. Hiller RM, Young RL, Weber N (2014) Sex Differences in Autism Spectrum Disorder based on DSM-5 Criteria: Evidence from Clinician and Teacher Reporting. J Abnorm Child Psychol 42(8): 1381-1393.

28. Mandy W, Chilvers R, Chowdhury U, Salter G, Seiga, A, et al. (2012) Sex Differences in Autism Spectrum Disorder: Evidence from a Large Sample of Children and Adolescents. J Autism Dev Disord 42(7): 13041313.

29. Morales Hidalgo P, Roigé Castellví J, Hernández Martínez C, Voltas N (2018) Prevalence and Characteristics of Autism Spectrum Disorder Among Spanish School-Age Children. J Autism Dev Disord 48(9): 31763190.

30. Loomes R, Hull L, Mandy WPL (2017) What Is the Male-to-Female Ratio in Autism Spectrum Disorder? A Systematic Review and MetaAnalysis. J Am Acad Child Adolesc Psychiatry 56(6): 466-474.

31. Freedman BH, Kalb LG, Zablotsky B, Stuart EA (2012) Relationship Status Among Parents of Children with Autism Spectrum Disorders: A Population-based Study. J Autism Dev Disord 42(4): 539-548.

32. Inegi (2017a) Estadísticas A Propósito Del Día De La Familia Mexicana (Estadístico) Aguascalientes, Ags: INEGI, p. 11.

33. INEGI. (2017b). Estadísticas A Propósito Del Día De La Madre (Estadístico), Aguascalientes, Ags p. 18

34. Méndez Ruiz Andres, Campos Vazquez R (2013) ¿Niña o niño? Un estudio sobre las preferencias de los padres mexicanos por el sexo de sus hijos. Estudios Económicos 28(2): 217-248.

35. Hultman CM, Sandin S, Levine SZ, Lichtenstein P, Reichenberg A (2011) Advancing paternal age and risk of autism: new evidence from a population-based study and a meta-analysis of epidemiological studies. Mol Psychiatry 16(12): 1203-1212.

36. Lampi KM, Hinkka Yli Salomäki S, Lehti V, Helenius H, Gissler M, et al. (2013a) Parental Age and Risk of Autism Spectrum Disorders in a Finnish National Birth Cohort. J Autism Dev Disord 43(11): 2526-2535.

37. Sandin S, Schendel D, Magnusson P, Hultman C, Surén P, et al. (2016a) Autism risk associated with parental age and with increasing difference in age between the parents. Mol Psychiatry 21(5): 693-700.

38. Idring S, Magnusson C, Lundberg M, Ek M, Rai D, et al. (2014) Parental age and the risk of autism spectrum disorders: findings from a Swedish population-based cohort. Int J Epidemiol 43(1): 107-115.

39. Croen LA, Najjar DV, Fireman B, Grether JK (2007) Maternal and 


\section{Global Journal of Intellectual \& Developmental Disabilities}

Paternal Age and Risk of Autism Spectrum Disorders. Arch Pediatr Adolesc Med 161(4): 334-340.

40. Durkin MS, Maenner MJ, Newschaffer CJ, Lee LC, Cunniff CM, et al. (2008) Advanced Parental Age and the Risk of Autism Spectrum Disorder. Am J Epidemiol 168(11): 1268-1276.

41. Janecka M, Mill J, Basson MA, Goriely A, Spiers H, et al. (2017) Advanced paternal age effects in neurodevelopmental disordersreview of potential underlying mechanisms. Translational Psychiatry 7 (1): e1019.

42. Cantor RM, Yoon JL, Furr J, Lajonchere CM (2007) Paternal age and autism are associated in a family-based sample. Molecular Psychiatry 12(5): 419-421.

43. D Onofrio BM, Rickert ME, Frans E, Kuja Halkola R, Almqvist C, et al. (2014) Paternal age at childbearing and offspring psychiatric and academic morbidity. JAMA psychiatry 71(4): 432-438.

44. Hultman, Christina M (2012) Advanced Paternal and Grandpaternal Age as a Risk Factor for Psychiatric Disorders. Schizophrenia Research 136: S3.

45. Lampi KM, Hinkka Yli Salomäki S, Lehti V, Helenius H, et al. (2013b). Parental Age and Risk of Autism Spectrum Disorders in a Finnish National Birth Cohort. J Autism Dev Disord 43(11): 2526-2535.

46. Lee BK, McGrath JJ (2015) Advancing parental age and autism: multifactorial pathways. Trends Mol Med 21(2): 118-125.

47. Lundström S, Haworth CM A, Carlström, E, Gillberg C, Mill J, et al (2010) Trajectories leading to autism spectrum disorders are affected by paternal age: findings from two nationally representative twin studies: Trajectories leading to autism spectrum disorders are affected by paternal age. J Child Psychol Psychiatry51(7): 850-856.

48. Parner ET, Baron Cohen S, Lauritsen MB, Jørgensen M, Schieve LA, et al. (2012) Parental Age and Autism Spectrum Disorders. Ann Epidemiol 22(3): 143-150.

49. Puleo CM, Reichenberg A, Smith CJ, Kryzak LA, Silverman JM (2008) Do autism-related personality traits explain higher paternal age in autism? Mol Psychiatry 13(3): 243-244.

50. Sandin S, Schendel D, Magnusson P, Hultman C, Surén P, et al. (2016b) Autism risk associated with parental age and with increasing difference in age between the parents. Mol Psychiatry 21(5): 693-700.

51. Baghdadli A, Picot MC, Pascal C, Pry R, Aussilloux C (2003) Relationship between age of recognition of first disturbances and severity in young children with autism. Eur Child Adolesc Psychiatry 12(3): 122-127.

52. De Giacomo A, Fombonne E (1998) Parental recognition of developmental abnormalities in autism. Eur Child Adolesc Psychiatry $7(3): 131-136$.

53. Tolbert L, Brown R, Fowler P, Parsons D (2001) Brief report: Lack of correlation between age of symptom onset and contemporaneous presentation. Journal of Autism and Developmental Disorders 31(2): 241-245.

54. Martinez M, Thomas KC, Williams CS, Christian R, Crais E, et al. (2018) Family Experiences with the Diagnosis of Autism Spectrum Disorder: System Barriers and Facilitators of Efficient Diagnosis. J Autism Dev Disord 48(7): 2368-2378.

55. Ribeiro SH, Paula CS de, Bordini D, Mari JJ, Caetano SC (2017) Barriers to early identification of autism in Brazil. Braz J Psychiatry 39(4): 352 354

56. Howlin, Patricia, Magiati I, Charman T (2009) Systematic Review of Early Intensive Behavioral Interventions for Children With Autism. Am J Intellect Dev Disabil 114(1): 23-41.

57. Howlin P, Asgharian A (1999) The diagnosis of autism and Asperger syndrome: findings from a survey of 770 families. Dev Med Child Neurol 41(12): 834-839.
58. Heinze G (2012) Los especialistas en psiquiatría en México: su distribución, ejercicio profesional y certificación 35(4): 7.

59. Heinze G, Chapa G del C, Carmona Huerta J (2016) Los especialistas en psiquiatría en México: año 2016. Salud Mental 39(2): 69-76.

60. Crane L, Chester JW, Goddard L, Henry LA, Hill E (2016b) Experiences of autism diagnosis: A survey of over 1000 parents in the United Kingdom. Autism 20(2): 153-162.

61. O Keeffe M, McDowell M (2004) Bridging the gap between health and education: Words are not enough. Journal of Paediatrics and Child Health 40(5-6): 252-257.

62. Grupo de Estudios de los Trastornos del Espectro Autista IIER/ISCIII (2004b). Informe sobre Demora Diagnóstica en los TEA (Investigación), Madrid, España: Instituto de Salud Carlos III, p. 1-43.

63. Sicherman N, Loewenstein G, Tavassoli T, Buxbaum JD (2016) Grandma knows best: Family structure and age of diagnosis of autism spectrum disorder. Autism 22(3): 368-376.

64. Brett D, Warnell F, Mc Conachie H, Parr JR (2016) Factors Affecting Age at ASD Diagnosis in UK: No Evidence that Diagnosis Age has Decreased Between 2004 and 2014. J Autism Dev Disord 46(6): 1974-1984.

65. Chakrabarti S (2009) Early identification of autism.

66. Chao K Y, Chang HL, Chin WC, Li HM, Chen SH (2018) How Taiwanese parents of children with autism spectrum disorder experience the process of obtaining a diagnosis: A descriptive phenomenological analysis. Autism 22(4): 388-400.

67. Daley TC (2004) From symptom recognition to diagnosis: children with autism in urban India. Soc Sci Med 58(7): 1323-1335.

68. Montiel Nava C, Chacín JA, González Ávila Z (2017) Age of diagnosis of autism spectrum disorder in Latino children: The case of Venezuelan children. Autism: The International Journal of Research and Practice 21(5): 573-580

69. Samms Vaughan M, Franklyn Banton L (2008) The role of early childhood professionals in the early identification of autistic disorder International Journal of Early Years Education 16(1): 75-84.

70. Talero Gutiérrez C, Rodríguez M, De La Rosa D, Morales G, Vélez Van Meerbeke A (2012) Profile of children and adolescents with autism spectrum disorders in an institution in Bogota, Colombia. Neurología (English Edition) 27(2): 90-96.

71. Mandell DS (2005) Factors Associated With Age of Diagnosis Among Children With Autism Spectrum Disorders. Pediatrics 116(6): 14801486.

72. Shattuck PT, Durkin M, Maenner M, Newschaffer C, Mandell DS, et al. (2009) Timing of Identification Among Children With an Autism Spectrum Disorder: Findings From a Population-Based Surveillance Study. J Am Acad Child Adolesc Psychiatry 48(5): 474-483.

73. Howlin, Patricia, Asgharian A (2007) The diagnosis of autism and Asperger syndrome: findings from a survey of 770 families. Developmental Medicine \& Child Neurology 41(12): 834-839.

74. Baio J, Wiggins L, Christensen DL, Maenner MJ, Daniels J (2018) Prevalence of Autism Spectrum Disorder Among Children Aged 8 Years - Autism and Developmental Disabilities Monitoring Network, 11 Sites, United States, 2014. MMWR Surveill Summ 67(6): 1-23.

75. Hussein H, Taha GR, Almanasef A (2011) Characteristics of autism spectrum disorders in a sample of egyptian and saudi patients: transcultural cross sectional study. Child Adolesc Psychiatry Ment Health 5(3): 34 .

76. Howlin, Patricia, Moore A (1997) Diagnosis in Autism: A Survey of Over 1200 Patients in the UK. Autism 1(2): 135-162.

77. Cohen SR, Miguel J (2018) Amor and Social Stigma: ASD Beliefs Among Immigrant Mexican Parents. J Autism Dev Disord 48(6): 1995-2009. 
78. Tuman J, Roth Johnson D, Baker LD, Vecchio Jennifer (2008) Autism and Special Education Policy in Mexico. Global Health Governance II 2(1): 2-22.

79. Zuckerman, Katharine E, Lindly OJ, Reyes NM, Chavez AE, et al. (2017) Disparities in Diagnosis and Treatment of Autism in Latino and NonLatino White Families. Pediatrics 139(5).

80. Zuckerman, Katharine E, Sinche B, Mejia A, Cobian M, et al. (2014) Latino parents' perspectives on barriers to autism diagnosis. Acad Pediatr14(3): 301-308.

81. Rhoades RA, Scarpa A, Salley B (2007) The importance of physician knowledge of autism spectrum disorder: results of a parent survey. BMC Pediatr 7(1): 37

82. Hooper S, Pretzel R (-) North Carolina State Implementation Project A proposal for submission to the Health Resources and Services Administration.

83. LXIII Camara de Diputados (2018) Ley General para la Atención y Protección a Personas con la Condición del Espectro Autista. Boletín No. 5374.
84. Cidav Z, Marcus SC, Mandell DS (2012) Implications of Childhood Autism for Parental Employment and Earnings. Pediatrics 129(4): 617-623.

85. Comisión Nacional de Protección Social en Salud. (2018) Catálogo Universal de Servicios de Salud, CAUSES.

86. Howes OD, Rogdaki M, Findon JL, Wichers RH, Charman T, et al. (2018) Autism spectrum disorder: Consensus guidelines on assessment, treatment and research from the British Association for Psychopharmacology. J Psychopharmacol 32(1): 3-29.

87. (2018) 5374 - Aprueban dictamen en favor de los derechos de las personas en condición del espectro autista.

88. (2000) American Psychiatric Association \& American Psychiatric Association. In: Diagnostic and statistical manual of mental disorders: DSM-IV-TR ( $4^{\text {th }}$ edn.), Washington, DC, USA.

\section{Your next submission with Juniper Publishers will reach you the below assets}

- Quality Editorial service

- Swift Peer Review

- Reprints availability

- E-prints Service

- Manuscript Podcast for convenient understanding

- Global attainment for your research

- Manuscript accessibility in different formats

( Pdf, E-pub, Full Text, Audio)

- Unceasing customer service

Track the below URL for one-step submission https://juniperpublishers.com/online-submission.php 